\title{
CLONING, EXPRESSION, AND CHARACTERIZATION OF THREE RIBOSOMAL PROTEIN S13 GENES IN Sophora flavescens
}

\author{
CLONAGEM, EXPRESSÃO E CARACTERIZAÇÃO DE TRÊS PROTEÍNAS \\ RIBOSSOOMICAS S13 GENES EM Sophora flavescens
}

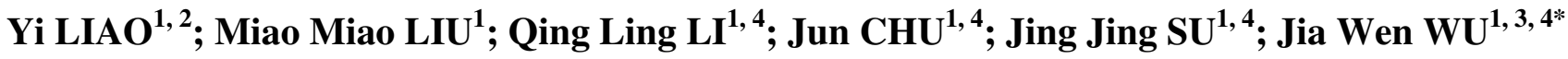 \\ 1. Key Laboratory of Xin'an Medicine, Ministry of Education, Anhui University of Traditional Chinese Medicine, China; 2. College of \\ Pharmacy, Anhui University of Traditional Chinese Medicine, China; 3. Synergetic Innovation Center of Anhui Authentic Chinese \\ Medicine Quality Improvement, China; 4. Anhui Academy of Chinese Medicine, China. wujiawen@ahtcm.edu.cn
}

\begin{abstract}
To characterize the structure and function of ribosomal protein S13 (RPS13), we identified fulllength open reading frames (ORFs) of three RPS13 genes (RPS13-1, RPS13-2, and RPS13-3) of the Chinese medicinal plant, Sophora flavescens. The target genes were amplified by reverse transcription-polymerase chain reaction (RT-PCR), ligated into the pET $22 \mathrm{~b}(+)$ vector, and then transformed into Escherichia coli BL21 competent cells for protein expression. The physicochemical properties, protein motif, evolution, and structural organization of the three RPS13 genes were analyzed using bioinformatics tools. The full-length ORFs (453 bp) of the three RPS13 genes of S. flavescens were cloned, and each encodes a protein of 151 amino acids in length, and their expression was detected by Western blotting. Bioinformatics analysis showed that RPS13s are stable proteins that are closely related to the 40S RPS13s of Vigna radiate var. radiate. Their three-dimensional structures included three $\alpha$-helices at the $\mathrm{C}$-terminal and four $\alpha$-helices at the $\mathrm{N}$-terminal, and the two clusters of helices were connected by a long random coil, which may help maintain the dynamic bridging interactions between the large and small subunits of the ribosome. The full-length ORFs of three RPS13 genes of S. flavescens were successfully cloned and expressed in vitro. The study of the physicochemical properties, evolution, and secondary and three-dimensional structures of the three proteins will provide the theoretical basis for further studies on the function of RPS13s in plants.
\end{abstract}

KEYWORDS: Bioinformatics analysis. Gene cloning. Ribosomal Protein S13. Sophora flavescens.

\section{INTRODUCTION}

The ribosome is the central site of protein synthesis, and is assembled in a precise and efficient fashion (MOLLIER et al., 2002). In general, eukaryotic ribosomes are composed of two subunits (40S and 60S), which both contain four RNAs and $70-80$ proteins (WOOL, 1979; MAGER, 1988). It is widely accepted that ribosomal proteins are the main component of the ribosome, and they are capable of binding to different specific ribosomal RNA (rRNA) species in the mature ribosomal subunit (MALYGIN, 2007; GUO et al., 2011) and play important roles in translation (WOOL, 1996). The majority of the translation reactions at the active site are catalyzed by rRNAs (NISSEN; STEITZ, 2000). Ribosomal proteins regulate the biosynthesis of proteins that are essential to cell survival, as well as function in various intracellular processes (ZHANG et al., 2003; JANG et al., 2004). There is increasing evidence suggesting that ribosomal proteins are involved in translational regulation, malignant transformation, and cell apoptosis (VAARALA et al., 1998; STONELEY; WILLIS, 2003; CLEMENS, 2004; LIAN et al., 2004). In recent years, the differential expression of ribosomal proteins has been implicated in specific human disorders. For example, missense mutations of the ribosomal protein $S 19$ (RPS19) gene have been shown to cause diamond-blackfan anemia (DBA) (OZONO et al., 2016). Chen et al. reported that the downregulation of RPS6 suppresses the growth of non-small cell lung cancer cells mainly by inducing cell cycle arrest (CHEN et al., 2014).

RP genes also play important roles in plants. Zheng et al. demonstrated that mutations and deletions involving the $R P L 3 B$ gene cause aberrant growth and development in leaves and stems of rice (ZHENG et al., 2016). Williams et al. have reported that oxygen deprivation and heat shock reduces the accumulation of phosphorylated RPS6 in the root tips of maize, whereas cold stress promotes the phosphorylation of RPS6 (WILLIAMS et al., 2003). Zhang et al. reported that plastid RPS5 enhances cold stress tolerance in Arabidopsis, thereby mediating plant growth and development (ZHANG et al., 2016).

Recent studies have suggested that RPs contribute to disease resistance in plants. Di et al. confirmed that the overexpression of RPL3 (the Nterminal encodes the first 99 amino acids of the protein) leads to trans-dominant resistance to pokeweed antiviral protein and the Fusarium mycotoxin deoxynivalenol of tobacco (DI; TUMER, 
2007). Nagaraj et al. found that RPL12 and RPL19 play an important role in nonhost disease resistance in Nicotiana benthamiana and Arabidopsis (NAGARAJ et al., 2016). Qian et al. reported that cotton RPL18 expression levels can mediate resistance to Verticillium dahliae through the SA signaling pathway (QIAN et al., 2017).

The RPS13s are the key members of the ribosomal protein family. Earlier studies have cloned and expressed human, catfish, and giant panda RPS13s (CHADÉNEAU et al., 1993; PORTA; MARGOLIS, 1995; SONG et al., 2011). Denis et al. found that RPS13s are overexpressed in colon cancer and other proliferating cells, and the levels of expression are significantly correlated to their growth rates (DENIS et al., 1993). Guo et al. have shown that the overexpression of RPS13s in gastric cancer cells imparts a protective effect against drug-induced apoptosis, indicating that it may be a potential biomarker for targeted therapy of gastric cancer (GUO et al., 2011). The root of $S$. flavescens has been historically employed in traditional Chinese medicine, and its active constituents include alkaloids and flavonoids (MA et al., 2008; LIU et al., 2010; HUANG; CHEN, 2013; ZHENG et al., 2014). These active compounds have a variety of pharmacological activities, which include anti-tumor, anti-bacterial, anti-inflammatory, and analgesic effects (JIN et al., 2010; SUN et al., 2012; WANG et al., 2015; YANG et al., 2015). Despite these extensive studies in humans and other animals, investigations on the RPS13s in plants are limited. In this study, three RPS13 genes of $S$. flavescens were successfully cloned and expressed in vitro The cloning, expression, and characterization of RPS13s will provide basic information for the elucidation of its function in $S$. flavescens and other plants.

\section{MATERIAL AND METHODS}

\section{Plant materials, bacterial strains, and reagents}

$S$. flavescens plants were grown at the Medicine Park of Anhui University of Traditional Chinese Medicine. E. coli DH5 $\alpha$ and BL21 cells were given as a gift by Professor Yunyu Shi (University of Science \& Technology, China). The pMD19-T vector, Taq DNA polymerase, T4 DNA ligase, all of the restriction endonucleases, and isopropyl- $\beta$-D-1-thiogalactoside (IPTG) were obtained from TaKaRa Biotechnology (Dalian) Co., Ltd. The AxyPrep ${ }^{\mathrm{TM}}$ DNA gel extraction kit (50 prep) and AxyPrep ${ }^{\mathrm{TM}}$ plasmid miniprep kit (50 prep) were purchased from Axygen Scientific. Inc. (USA). The E.Z.N.A Plant RNA Kit (50) was purchased from OMEGA Bio-Tek (USA). The RevertAid First Strand cDNA synthesis kit was purchased from Thermo Fisher Scientific.

\section{RNA isolation and cDNA synthesis}

Frozen roots, stems, and leaves of $S$. flavescens were ground into a fine powder in liquid nitrogen. Total RNA was purified using the E.Z.N.A Plant RNA kit (50) following the manufacturer's instructions. The purity and integrity of total RNA was analyzed by measuring the optical density ratio $\left(\mathrm{OD}_{260 \mathrm{~nm}} / \mathrm{OD}_{280 \mathrm{~nm}}\right)$ and $1 \%$ agarose gel electrophoresis. The quantified total RNA was used in the synthesis of single-stranded cDNAs with the RevertAid First Strand cDNA synthesis kit (Thermo, USA).

\section{Primer design}

Based on the RPS13 unigenes from the transcriptional database of $S$. flavescens (HAN et al., 2015), the primers of the RPS13 genes were designed using Primer Premier 5.0. The following primers were used:

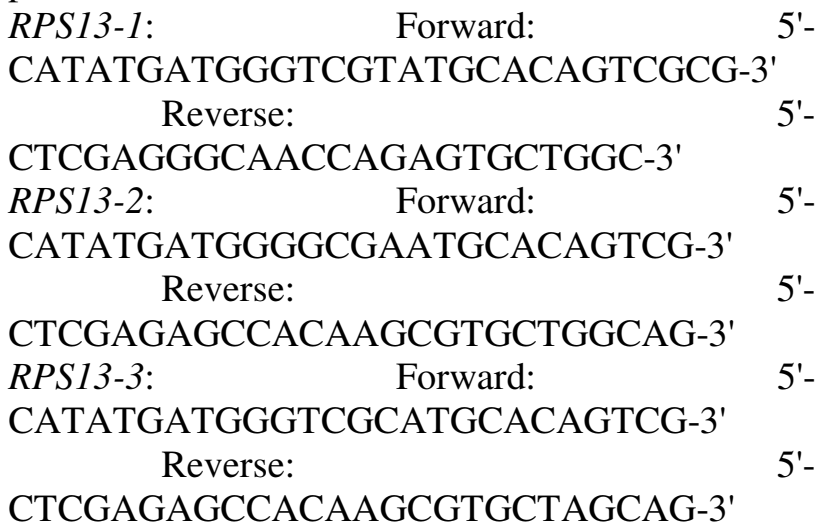

\section{Gene amplification}

The three RPS13 genes were amplified by reverse transcription-polymerase chain reaction (RT-PCR) using the cDNA from leaves of $S$. flavescens as a template. The resulting PCR fragments were then cloned. The amplification system was based on the manufacturer's instructions. The conditions of the two-step RTPCRs were as follows: pre-denaturation at $94^{\circ} \mathrm{C}$ for 3 min, followed by the first step that consisted of 10 cycles of $94^{\circ} \mathrm{C}$ for $30 \mathrm{~s}, 40^{\circ} \mathrm{C}$ for $30 \mathrm{~s}$, and $72^{\circ} \mathrm{C}$ for $1 \mathrm{~min}$; and the second step that comprised 25 cycles of $94^{\circ} \mathrm{C}$ for $30 \mathrm{~s}, 50^{\circ} \mathrm{C}$ for $30 \mathrm{~s}$, and $72^{\circ} \mathrm{C}$ for $1 \mathrm{~min}$. The duration of the $72^{\circ} \mathrm{C}$ elongation step was 10 min, and the holding temperature was $4^{\circ} \mathrm{C}$. The PCR products were confirmed by $1 \%$ agarose gel electrophoresis. The target fragments were ligated into the pMD19-T vector, followed by transformation into E.coli DH5a competent cells 
using heat shock. The selected individual colonies by ampicillin resistance screening were inoculated into liquid LB containing $50 \mathrm{mg} / \mathrm{mL}$ of ampicillin to augment the plasmid.

\section{Construction of pET22b (+)-RPS13 expression vector}

The recombinant plasmid pMD19-RPS13 was verified by sequencing and double digestion with restriction enzymes NdeI and XhoI to obtain the target genes. These genes were ligated into the expression vector $\mathrm{pET} 22 \mathrm{~b}(+)$, and the recombinant pET22b(+)-RPS13 plasmids were verified by sequencing (Sangon Biotech, Shanghai, China).

\section{Bioinformatics analysis}

The DNA sequence analysis software DNAMAN 6.0.3.99 was used to align the nucleotide sequences of the three RPS13 cDNA genes. ClustalX 1.83 software (JEANMOUGIN et al., 1998) and ESPript 3.0 program (GOUET et al., 1999) were used to analyze the secondary structure and align the amino acid sequences of the RPS13s. The physicochemical properties of the three RPS13s were calculated using the ProtParam tool, which is available on the ExPASy molecular biology server (WILKINS et al., 1999). The functional sites and domains of the three RPS13s were predicted by the Motif scan software. SMART BLAST was used for sequence alignment against the database sequences, and the highest identity of Fabaceae plants were selected and used in homologous comparisons. Furthermore, the phylogenetic tree of the RPS13s was constructed by the neighbor-joining method using MEGA 5.0 program (TAMURA et al., 2011) with 1,000 bootstrap replicates. The threedimensional (3D) models of the three RPS13s were generated using SWISS-MODEL software (ARNOLD et al., 2006; BENKERT et al., 2011; BIASINI et al., 2014) and PyMOL program (DeLano, 2002).

\section{Induced expression of the RPS13s and Western blot analyses}

The recombinant pET22b(+)-RPS13 plasmids were transformed into $E$. coil BL21 competent cells for His-tagged protein expression. The BL21 cells were then induced by different concentrations of IPTG $(0 \mathrm{mM}, 0.1 \mathrm{mM}, 0.5 \mathrm{mM}$, and $1 \mathrm{mM}$ ) at $16^{\circ} \mathrm{C}, 25^{\circ} \mathrm{C}$, or $37^{\circ} \mathrm{C}$ for $24 \mathrm{~h}, 8 \mathrm{~h}$, and $6 \mathrm{~h}$, respectively. The induced BL21 cells were harvested by centrifugation at $8,000 \mathrm{rpm}$ for $15 \mathrm{~min}$, then fragmented by ultrasonication. The resulting fragments were then centrifuged at 13,000 rpm for $30 \mathrm{~min}$ to separate the supernatant and the sediment.
For Western blot analyses, $30 \mu \mathrm{L}$ of the supernatants was run on $15 \%$ SDS-polyacrylamide gel and then transferred onto polyvinylidene difluoride membranes. The membranes were blocked with PBS buffer containing 0.1\% Tween-20 (PBST) and 5\% non-fat dry milk followed by a $1 \mathrm{~h}$ incubation at $37^{\circ} \mathrm{C}$, and then washed thrice with PBST buffer. Next, the membranes were incubated with the His-Tag antibody (1/1000) (mouse monoclonal antibody, AM1010a, Abgent, China) overnight at $4^{\circ} \mathrm{C}$. The membranes were then washed thrice with PBST buffer and subsequently incubated with a second antibody $(1 / 2,500)$ anti-mouse IgG HRP conjugate (W402B, Promega, China) for $2 \mathrm{~h}$ at room temperature. Finally, all of the membranes were developed using a Immobilon ${ }^{\mathrm{TM}}$ western kit (Millipore Corporation, Billerica, USA) and detected using a ChemiDoc (BioRad, USA) imaging system.

\section{RESULTS}

\section{Isolation and identification of RNA in $S$. flavescens}

The E.Z.N.A Plant RNA Kit (50) was used to extract the RNA from $S$. flavescens, and the integrity of the RNA was subsequently identified by electrophoresis and spectrophotometry. The $\mathrm{OD}_{260 \mathrm{~nm}} / \mathrm{OD}_{280 \mathrm{~nm}}$ ratio was 1.83 . Figure $1 \mathrm{~A}$ shows that the $28 \mathrm{~S}$ and $18 \mathrm{~S}$ rRNA bands in the extracted total RNA were clear and bright, and their ratio appeared to be almost 1:1, indicating that the extracted total RNA was of good quality and yield.

\section{PCR amplification and identification of RPS13 genes}

Total RNA was used for cDNA synthesis, then the three target genes were amplified by Taq PCR using cDNA as template. The amplification of RPS13-1, RPS13-2, and RPS13-3 was detected by electrophoresis (Figures 1 B-D, respectively, arrow). These results suggest that the 453-bp full-length open reading frames (ORFs) of the three RPS13 genes were successfully cloned. These three RPS13 cDNAs were submitted to GenBank as accession numbers KY608742 (RPS13-1), KY608743 (RPS13-2), and KY608744 (RPS13-3). The pMD19RPS13 recombinants were constructed and transformed into E. coli DH5 $\alpha$ cells. The recombinant plasmids were further verified by PCR and subjected to double enzyme digestion using NdeI and XhoI. The target gene sequences were confirmed by DNA sequencing to be $100 \%$ identical to the RPS13 unigenes from the transcriptional database of $S$. flavescens (data not shown). 

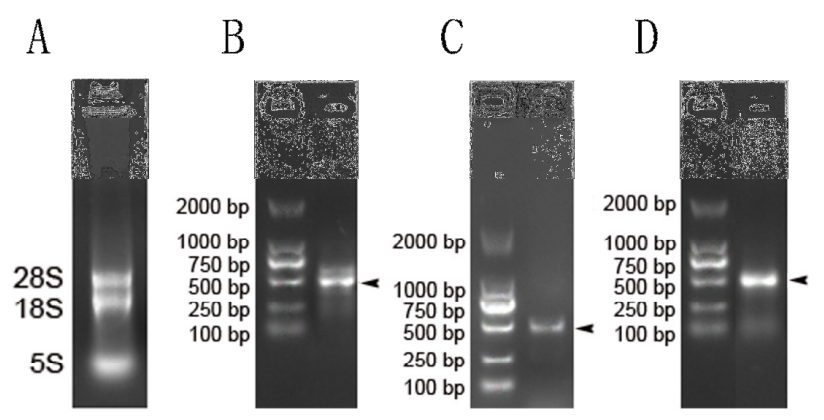

Figure 1. A, Total RNA isolation. $\mathrm{B}, \mathrm{C}, \mathrm{D}$, Cloning of three RPS13 genes (B, RPS13-1; C, RPS13-2; D, RPS13-3, shown as arrows).

Construction of recombinant plasmid of pET22b (+)-RPS13

The RPS13 genes were ligated into a $\mathrm{pET} 22 \mathrm{~b}(+)$ vector for protein expression. The results of bacteria liquid PCR and double enzyme digestion identification are shown in the Figure 2. The arrows indicate the location of the RPS13 genes. The recombinant plasmid pET22b(+)-RPS13 was confirmed again by DNA sequencing.
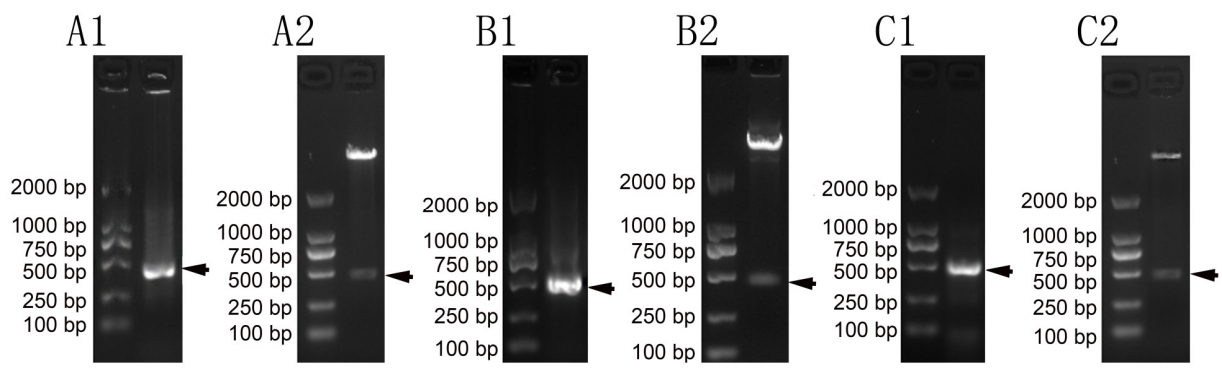

Figure 2. Identification of recombinant plasmid pET22b(+)-RPS13. Note: (A1, B1, C1) Identification of bacteria liquid PCR of the three recombinant plasmids (arrows); (A2, B2, C2) Identification of double digestion of the three recombinant plasmids (arrows show the target genes).

\section{Bioinformatics analysis}

DNA and protein sequences alignment of the three RPS13 genes

The results of DNA and protein sequence alignment are shown in Figure 3. DNA sequence identity of these three proteins was $98.83 \%$ (Figure 3 A). Comparison of the deduced RPS13s amino acid sequences indicated that the RPS13-1 sequences share $99.12 \%$ and $98 \%$ identity with RPS13-2 and RPS13-3, respectively (Figure $3 \mathrm{~B}$ ). The three cDNA fragments of the RPS13 all contain a full-length ORF of $453 \mathrm{bp}$, which encode a 151amino acid protein. Nucleotide differences were observed among the ORFs of the three RPS13 genes; however, most of these were synonymous mutations such as those at positions $6,21,72,348$,
438, 444, 447, 450, and 453. These synonymous mutations do not result in amino acid substitutions.

The amino acid sequence alignment of the three RPS13s showed that RPS13-1 is only slightly different from RPS13-2 and RPS13-3. Position 3 is located in the $\mathrm{N}$-myristoylation site; there is a cysteine (Cys) at position 3 in the RPS13-1, but RPS13-2 and RPS13-3 have an arginine (Arg) at this site. Also, position 17 is located within the protein kinase $\mathrm{C}$ phosphorylation site; there is a serine (Ser) at position 17 in the RPS13-3, but RPS13-1 and RPS13-2 have a proline (Pro) at this site. Apparently, the Cys at position 3 and Ser at position 17 are the key amino acids for the $\mathrm{N}$ myristoylation of RPS13-1 and the protein kinase C phosphorylation of RPS13-3, respectively. 


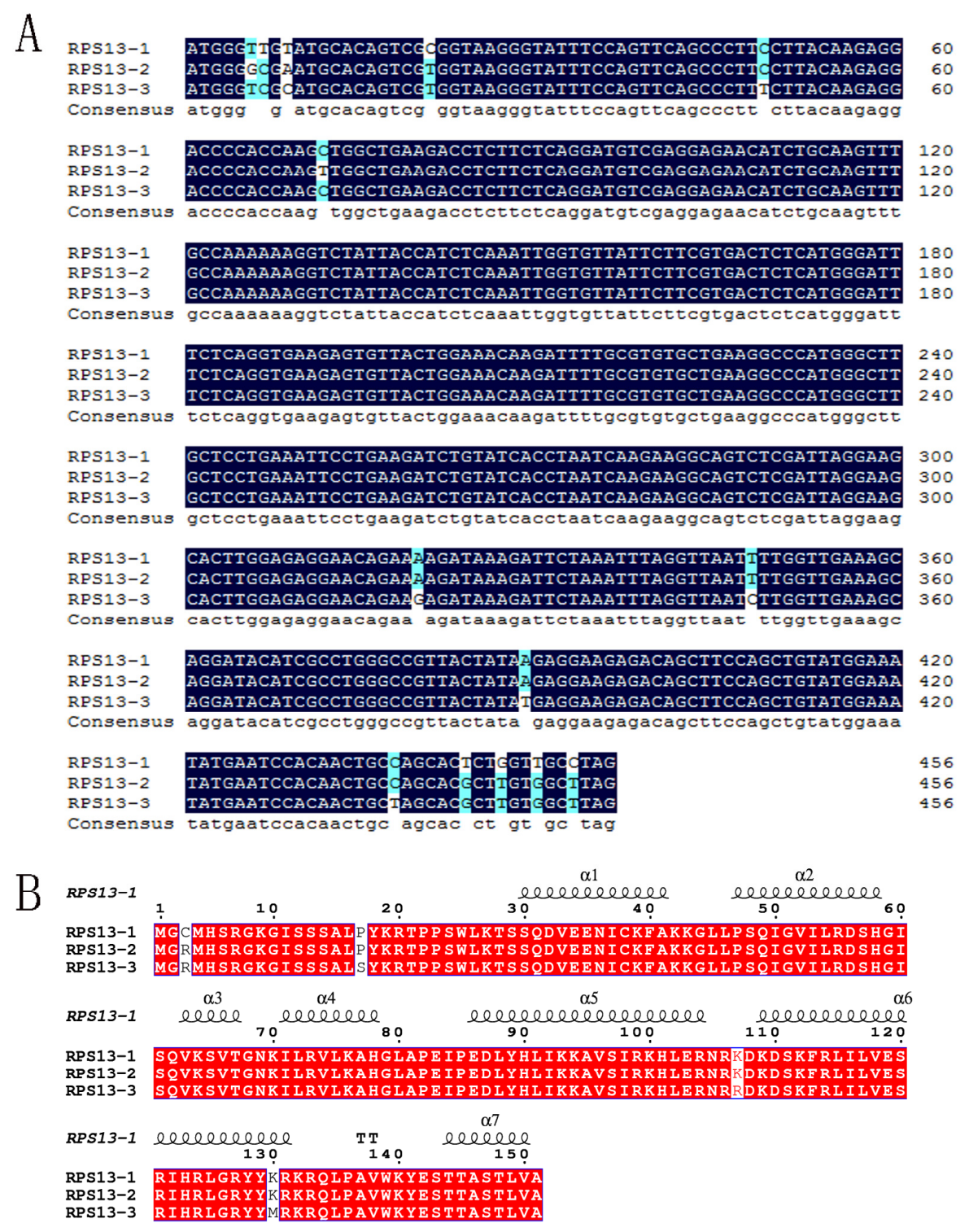

Figure 3. Sequence alignment of three RPS13s of S. flavescens. A, DNA sequence alignment of the three RPS13 genes. The same bases are colored in white in the dark blue column; the distinct sections are colored in black. B, Protein sequences alignment of RPS13s. The same sequences are colored in white in the red column; the distinct sections are colored in black. The secondary structures of the RPS13-1 protein are shown above the sequences, with helices as squiggles and turns as TT.

\section{Analysis of the physicochemical properties}

The physicochemical properties of the three proteins are similar (Table 1). Their molecular weights were about $17 \mathrm{kD}$, isoelectric point (PI)s were approximately 10.50 , and a higher number of positively charged amino acids were observed compared to negatively charged amino acids. These findings suggest that the three proteins are alkaline proteins.

\section{Protein motifs and structural domains}

Analysis of the motif scan indicated that the RPS13s contain a variety of motifs such as the casein kinase II phosphorylation site, Nmyristoylation site, and protein kinase $\mathrm{C}$ phosphorylation site. Table 2 shows that the motif positions are similar in the three proteins except for the N-myristoylation site of G2-R7 in RPS13-1 and the protein kinase $\mathrm{C}$ phosphorylation site of S17K19 in RPS13-3. 
Table 1. Physicochemical properties of the RPS13s

\begin{tabular}{llll}
\hline Characteristics & RPS13-1 & RPS13-2 & RPS13-3 \\
\hline Molecular weight & $17173.13 \mathrm{Da}$ & $17226.18 \mathrm{Da}$ & $17247.18 \mathrm{Da}$ \\
Isoelectric point (PI) & 10.34 & 10.51 & 10.56 \\
Negatively charged amino acids (ASP+Glu) & 12 & 12 & 12 \\
Positively charged amino acid (Arg+Lys) & 31 & 32 & 31 \\
Instability coefficient & 60.69 & 58.53 & 61.30 \\
Aliphatic index & 92.32 & 92.32 & 92.32 \\
Grand average of hydropathicity (GRAVY) & -0.514 & -0.560 & -0.521 \\
\hline
\end{tabular}

\begin{tabular}{|c|c|c|c|}
\hline Motif information & Position in RPS13-1 & Position in RPS13-2 & Position in RPS13-3 \\
\hline $\begin{array}{l}\text { Casein kinase II phosphorylation } \\
\text { site }\end{array}$ & S29-D32 & S29-D32 & S29-D32 \\
\hline $\mathrm{N}$-myristoylation site & $\begin{array}{l}\text { G2-R7, G10-A15, G44- } \\
\text { Q49 }\end{array}$ & G10-A15, G44-Q49 & G10-A15, G44-Q49 \\
\hline $\begin{array}{l}\text { Protein kinase } \mathrm{C} \text { phosphorylation } \\
\text { site }\end{array}$ & S97-R99 & S97-R99 & S97-R99, S17-K19 \\
\hline Ribosomal protein S15 signature & I98-Y128 & I98-Y128 & I98-Y128 \\
\hline 30S ribosomal protein $\mathrm{S} 15$ & R3-L149 & R3-L149 & R3-L149 \\
\hline Bipartite nuclear localization signal & K93-D110 & K93-D110 & K93-D110 \\
\hline $\begin{array}{l}\text { Ribosomal S13/S15 N-terminal } \\
\text { domain }\end{array}$ & M1-I60 & M1-I60 & M1-I60 \\
\hline Ribosomal protein S15 & S65-A151 & S65-A151 & S65-A151 \\
\hline
\end{tabular}

\section{Phylogenetic tree analysis of homologous proteins}

The three RPS13 sequences of $S$. flavescens were $453 \mathrm{bp}$ in length. These sequences were compared to those in the database of known RPS13 sequences. Homology analysis showed that the sequence similarity of this plant to the Fabaceae family was $>90 \%$ (Figure 4). The three RPS13 gene sequences were submitted to the GenBank as accession numbers KY608742, KY608743, and KY608744. As shown in the phylogenetic tree constructed using MEGA5, the RPS13s of $S$. flavescens were related to 40S RPS13 of Vigna radiata var. radiate (GenBank Accession number XP_014509360.1), with a similarity of 93\%. Therefore, $S$. flavescens is most closely related to Vigna radiata var. radiate.

\section{Secondary structure prediction and 3D modeling}

The 3D models (Figure 5) of the three RPS13s were produced using the structures of $4 \mathrm{~d} 61$ and 4kzz as templates (Lomakin and Steitz, 2013; Muhs et al., 2015). The $4 \mathrm{~d} 61$ and $4 \mathrm{kzz}$ are Protein
Data Bank entries, where $4 \mathrm{~d} 61$ refers to the cryoEM structures of ribosomal 80S complexes, whereas $4 \mathrm{kzz}$ refers to the crystal structure of the rabbit $40 \mathrm{~S}$ ribosomal subunit. Based on the 3D models of RPS13s, the results of secondary structure analysis are shown in Figure $3 \mathrm{~B}$. The structure of ribosomal protein S13 is rich in $\alpha$-helices. There are seven $\alpha$ helixes in these proteins, namely, S30-A41 $(\alpha 1)$, P47- H58 ( $\alpha 2)$, V63-T67 ( $\alpha 3)$, K71- H78 ( $\alpha 4)$, E86R104 ( $\alpha 5)$, K109-R131 ( $\alpha 6)$, and T144-V150 ( $\alpha 7)$, respectively. The 3D structure of the three RPS13s included three $\alpha$-helixes at the $\mathrm{C}$-terminal and four $\alpha$-helixes at the N-terminal, and the two clusters of helices were connected by a long random coil (Figure 5). 


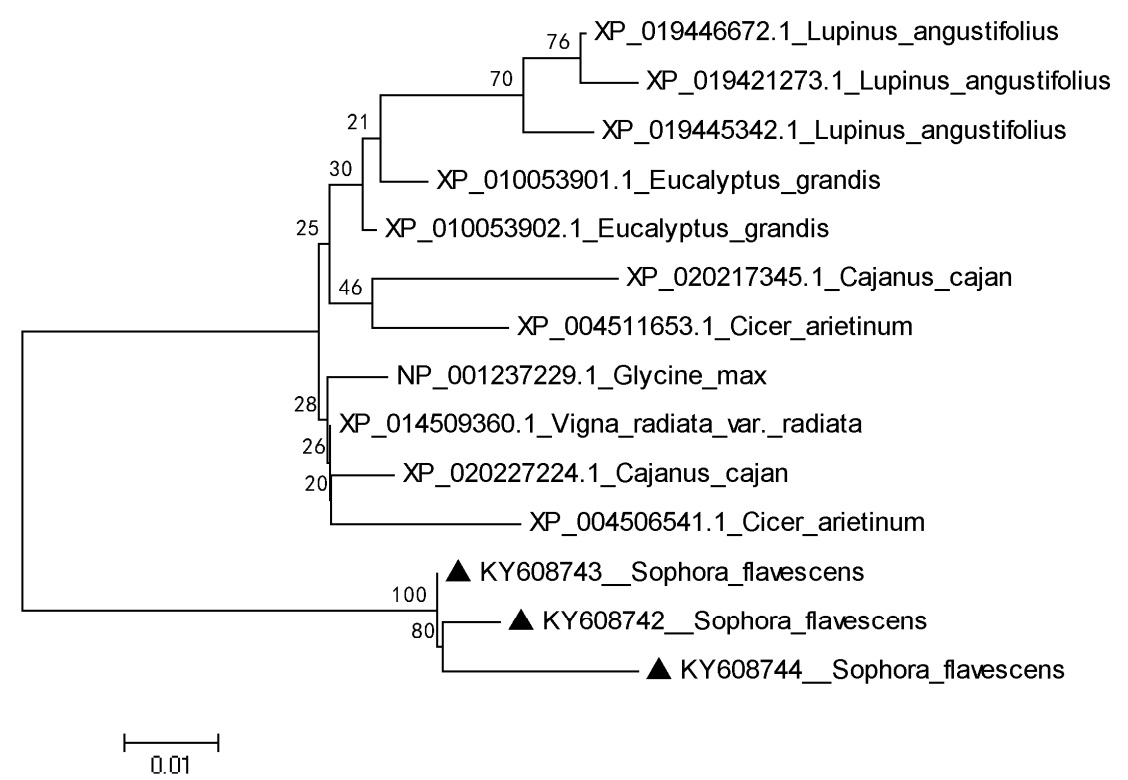

Figure 4. Phylogenetic analysis of RPS13s from S. flavescens and other Fabaceae plants. Bootstrap values based on 1,000 replications are shown at the branching points. The bar (0.01) shows the genetic distance.
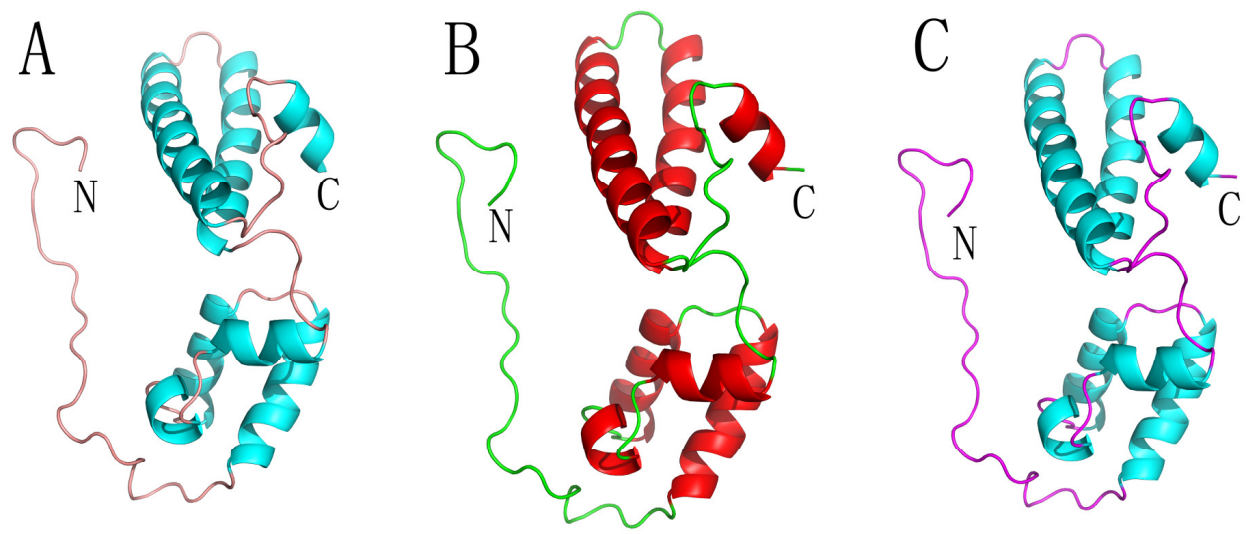

Figure 5. 3D models of RPS13s. (A) The 3D model of RPS13-1. Template: 4d61.1.O, Sequence Identity $75.5 \%$, Sequence Similarity 53\%, Coverage 100\%; (B) The 3D structure of RPS13-2. Template: 4d61.1.O, Sequence identity 76.16\%, Sequence similarity 53\%, Coverage 100\%; (C) The 3D structure of RPS13-3. Template: 4kzz.1.N, Sequence identity 74.17\%, Sequence Similarity 52\%, Coverage $100 \%$.

\section{RPS13s expression}

The results of Western blot analysis are shown in the Figures 6A-C. Distinct bands of about $17 \mathrm{kD}$ molecular mass were observed, which are consistent with the theoretical molecular weight of RPS13s. The target proteins were mainly detected in the supernatant. The relative expression level of the RPS13s showed that the optimal induction conditions for RPS13-1/2/3 expression was 0.5 $\mathrm{mmol} / \mathrm{L}$ IPTG at $16^{\circ} \mathrm{C}$ for $24 \mathrm{~h}, 1 \mathrm{mmol} / \mathrm{L}$ IPTG at $25^{\circ} \mathrm{C}$ for $8 \mathrm{~h}$, and $0.1 \mathrm{mmol} / \mathrm{L}$ IPTG at $25^{\circ} \mathrm{C}$ for $8 \mathrm{~h}$, respectively (Figures $6 \mathrm{D}-\mathrm{F}$ ). 

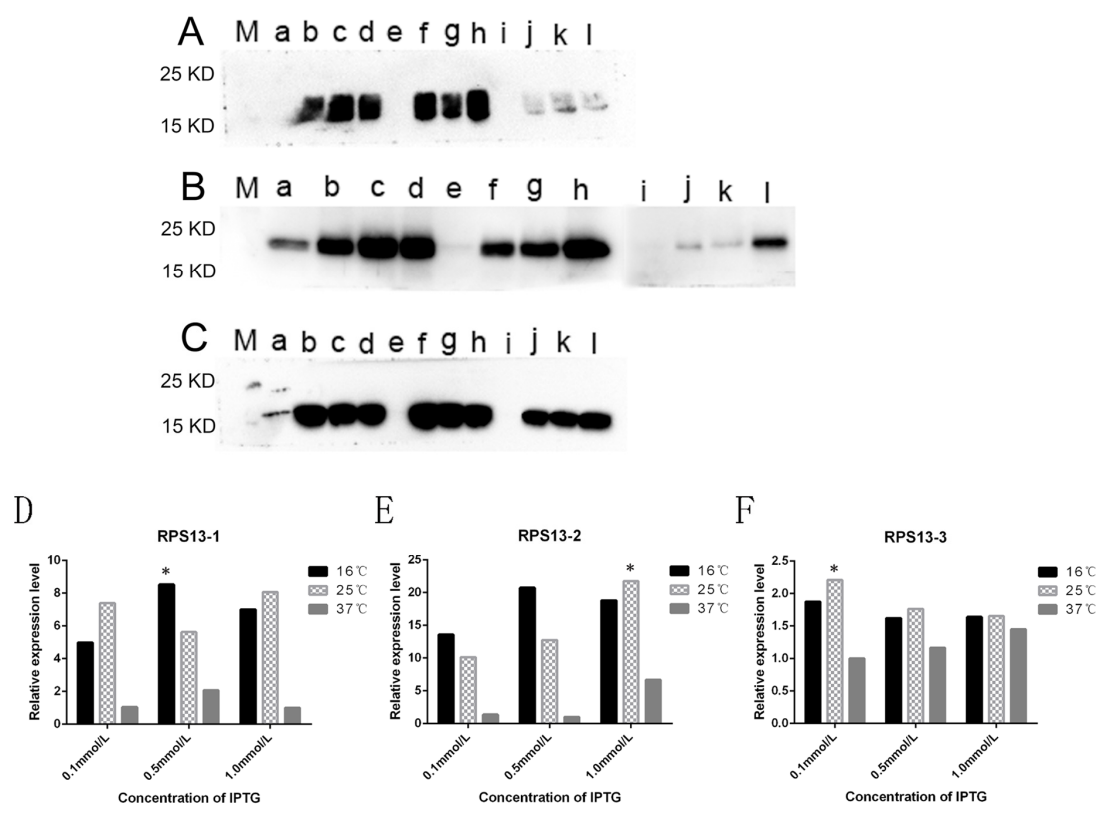

Figure 6. Expression of the three RPS13s of S. flavescens. (A), (B), (C) Expression of RPS13-1, RPS13-2, and RPS13-3 in E. coli BL21 cells. Lane M: protein molecular weight marker. E. coli BL21 cells were induced with $0,0.1,0.5$, or $1.0 \mathrm{mM}$ PRTG at different temperatures and durations. Lanes a-d: $16^{\circ} \mathrm{C}$ for $24 \mathrm{~h}$. Lanes e-h: $24^{\circ} \mathrm{C}$ for $8 \mathrm{~h}$. Lane i-l: $37^{\circ} \mathrm{C}$ for $6 \mathrm{~h}$. (D), (E), (F) The relative level of RPS131/2/3 expression in E. coli BL21 cells. Asterisks indicate the highest expression levels.

\section{DISCUSSION}

The present study focused on the cloning, expression, and characterization of three RPS13s of $S$. flavescens. The three cDNA fragments of the RPS13 all contain a full-length ORF of $453 \mathrm{bp}$, which encodes a protein consisting of 151 amino acids. There are some different bases between the ORFs of the three RPS13 genes; however, most of these were synonymous mutations, and their protein sequences only slightly differed from each other, and thus are considered as gene polymorphisms. The gene polymorphism signified a development in human and plant genetics research.

The sequence of the three RPS13s of $S$. flavescens showed a high degree of homology to the 40S RPS13 of other Fabaceae plants, with identities $>90 \%$. The striking homology of the S. flavescens RPS13s to the RPS13s of other Fabaceae species indicates that this protein is highly conserved. This observation also suggests that the RPS13 genes of $S$. flavescens and the other Fabaceae species have highly similar functions, as supported by the results of domain and motif analyses.

RPS13s is located in the head area of the small subunit of the ribosome, where it provides multiple contacts with the large subunit and the Psite tRNA anticodon region through its extended $\mathrm{C}$ terminus (YUSUPOV et al., 2001). The 3D structure models of RPS13s of $S$. flavescens showed that these proteins have a spiral structure consisting of two clusters of helices that are connected by a long random coil, which may help to maintain the dynamic bridging interactions between the large and small subunits of the ribosome. RPS13-mediated interactions are likely to play a significant role in orchestrating protein translation.

The RPS13 genes play essential roles in regulating plant development and possibly contribute to the evolution of plants. Ito et al. found that ribosomal protein S13 mutants can causes plant developmental anomalies, such as disturbances of leaf development as well as delay in root growth and flowering (ITO et al., 2000). Kim et al. identified that the expression of the RPS13 gene in soybean increases during low-temperature stress, possibly enhancing protein translation or assisting in ribosome assembly (KIM et al., 2004). Our next study will focus on elucidating the functional role of RPS13s in S. flavescens. The present study provides a foundation for exploring the mechanism of RPS13 gene regulation in relation to the growth and development of $S$. flavescens and other plants. 


\section{ACKNOWLEDGEMENTS}

This research was supported by Natural Science Foundation of Anhui Province of China (Grant No.1608085MH177); Natural Science Research Grant of Higher Education of Anhui Province (Grant No. KJ2018ZD028); Project of Sustainable Utilization of Famous Traditional Chinese Medicine Resources (Grant No. 2060302); Anhui Province Scientific Research Foundation for the Returned Overseas Chinese Scholars (Grant No.20151x024); the Initial Founding of Scientific Research for the Introduction of Talents (Anhui University of Traditional Chinese Medicine, Grant No. 2015RC002); The Key Projects of Anhui Province University Outstanding Youth Talent Support Projects (gxyqZD2016139). The authors thank Qingshan Yang for identifying the plant materials.

RESUMO: Objetivo: Para caracterizar a estrutura e a função da proteína ribossomal S13 (RPS13), identificamos fases de leitura abertas (ORFs) completas de três genes RPS13 (RPS13-1, RPS13-2 e RPS13-3) da planta medicinal chinesa, Sophora flavescens. Métodos: Os genes alvo foram amplificados por reação em cadeia da polimerase por transcrição reversa (RT-PCR), ligados ao vetor pET22b(+), e então transformados em células competentes de Escherichia coli BL21 para expressão protéica. As propriedades físico-químicas, o motivo protéico, a evolução e a organização estrutural dos três genes RPS13 foram analisados utilizando ferramentas de bioinformática. Resultados: ORFs completos (453 pb) dos três genes RPS13 de S. flavescens foram clonados, e cada um codifica uma proteína de 151 aminoácidos de comprimento, e sua expressão foi detectada por western blotting. A análise de bioinformática mostrou que as RPS13s são proteínas estáveis que estão intimamente relacionadas com as 40S RPS13s de Vigna radiata var. radiate. Suas estruturas tridimensionais incluíam três $\alpha$-hélices no $\mathrm{C}$-terminal e quatro $\alpha$-hélices no $\mathrm{N}$-terminal, e os dois aglomerados de hélices eram conectados por uma longa bobina aleatória, o que pode ajudar a manter as interações de ponte dinâmicas entre o subunidades grandes e pequenas do ribossomo. Conclusões: As ORFs completas de três genes RPS13 de S. flavescens foram clonadas e expressas com sucesso in vitro. $\mathrm{O}$ estudo das propriedades físico-químicas, evolução e estruturas secundárias e tridimensionais das três proteínas fornecerão a base teórica para estudos adicionais sobre a função das RPS13s em plantas.

PALAVRAS-CHAVE: Análise de bioinformática. Clonagem de genes. Proteína Ribossomal S13. Sophora flavescens

\section{REFERENCES}

ARNOLD, K.; BORDOLI, L.; KOPP, J.; SCHWEDE, T. The SWISS-MODEL workspace: a web-based environment for protein structure homology modelling. Bioinformatics, Oxford, v. 22, n. 2, p. 195-201, 2006. https://doi.org/10.1093/bioinformatics/bti770

BENKERT, P.; BIASINI, M.; SCHWEDE, T. Toward the estimation of the absolute quality of individual protein structure models. Bioinformatics, Oxford, v. 27, n. 3, p. 343-350, 2011.

https://doi.org/10.1093/bioinformatics/btq662

BIASINI, M.; BIENERT, S.; WATERHOUSE, A.; ARNOLD, K.; STUDER, G.; SCHMIDT, T.; KIEFER, F.; CASSARINO, T. G.; BERTONI, M.; BORDOLI, L.; SCHWEDE, T. SWISS-MODEL: modelling protein tertiary and quaternary structure using evolutionary information. Nucleic Acids Research, Oxford, v. 42, p. W252-W258, 2014. https://doi.org/10.1093/nar/gku340

CHADÉNEAU, C.; LEMOULLAC, B.; DENIS, M. G. Cloning and analysis of the human S13 ribosomal protein cDNA. Nucleic Acids Research, Oxford, v. 21, n. 12, p. 2142-2148, 1993.

https://doi.org/10.1093/nar/21.12.2945

CHEN, B. J.; ZHANG, W.; GAO, J.; CHEN, H.; JIANG, L.; LIU, D.; CAO, Y. D.; ZHAO, S.; QIU, Z. X.; ZENG, J.; ZHANG, S. F.; LI, W. M. Downregulation of ribosomal protein S6 inhibits the growth of non-small cell lung cancer by inducing cell cycle arrest, rather than apoptosis. Cancer Letters, Ireland, v. 354, n. 2, p. 378-389, 2014. https://doi.org/10.1016/j.canlet.2014.08.045 
CLEMENS, M. J. Targets and mechanisms for the regulation of translation in malignant transformation. Oncogene, London, v. 23, n. 18, p. 3180-3188, 2004.

DELANO, WL. The Pymol Molecular Visualization System. DeLano Scientific LLC: San Carlos, 2002. https://doi.org/10.1038/sj.onc.1207544

DENIS, M. G.; CHADENEAU, C.; LECABELL, M. T.; LEMOULLA, B.; LEMEVE, B.; MEFLA, K.; LUSTENBERG, P. Overexpression of the $\mathrm{S} 13$ ribosomal protein in actively growing cells. International Journal of Cancer, Hoboken, v. 55, n. 2, p. 275-280, 1993. https://doi.org/10.1002/ijc.2910550218

DI, R.; TUMER, N. E. Expression of a truncated form of ribosomal protein L3 confers resistance to pokeweed antiviral protein and the fusarium mycotoxin deoxynivalenol. Molecular Plant-microbe Interactions, St. Paul, v. 18, n. 8, p. 762-770, 2007. https://doi.org/10.1094/mpmi-18-0762

GOUET, P.; COURCELLE, E.; STUART, D. I.; METOE, F. Espript: analysis of multiple sequence alignments in postscript. Bioinformatics, Oxford, v. 15, n. 4, p. 305-308, 1999.

https://doi.org/10.1093/bioinformatics/15.4.305

GUO, X. Y.; SHI, Y. Q.; GOU, Y. W.; LI, J. P.; HAN, S.; ZHANG, Y. Q.; HUO, J. H.; NING, X. X.; SUN, L.; CHEN, Y.; SUN, S. R.; FAN, D. M. Human ribosomal protein S13 promotes gastric cancer growth through down-regulating p27kip1. Journal of Cellular and Molecular Medicine, Hoboken, v. 15, n. 2, p. 296-306, 2011. https://doi.org/10.1111/j.1582-4934.2009.00969.x

HAN, R. C.; TAKAHASHI, H.; NAKAMURA, M.; BUNSUPA, S.; YOSHIMOTO, N.; YAMAMOTO, H.; SUZUKI, H.; SHIBATA, D.; YAMAZAKI, M.; SAITO, K. Transcriptome Analysis of Nine Tissues to Discover Genes Involved in the Biosynthesis of Active Ingredients in Sophora flavescens. Biological and Pharmaceutical Bulletin, Tokyo, v. 38, n. 6, p. 876-883, 2015. https://doi.org/10.1248/bpb.b14-00834

HUANG, X. Y.; CHEN, C. X. Effect of oxymatrine, the active component from Radix Sophorae flavescentis (Kushen), on ventricular remodeling in spontaneously hypertensive rats. Phytomedicine, Jena, v. 20, n. 3-4, p. 202-212, 2013. https://doi.org/10.1016/j.phymed.2012.10.012

ITO, T.; KIM, G. T.; SHIOZAKI, K. Disruption of an Arabidopsis cytoplasmic ribosomal protein S13homologous gene by transposon-mediated mutagenesis causes aberrant growth and development. Plant Journal, Hoboken, v. 22, n. 3, p. 257-264, 2000. https://doi.org/10.1046/j.1365-313x.2000.00728.x

JANG, C. Y.; LEE, J. Y.; KIM, J. RPS3, a DNA repair endonuclease and ribosomal protein, is involved in apoptosis. FEBS Letters, Amsterdam, v. 560, n. 1-3, p. 81-85, 2004. https://doi.org/10.1016/s00145793(04)00074-2

JEANMOUGIN, F.; THOMPSON, J. D.; GOUY, M.; HIGGINS, D. G.; GIBSON, T. J. Multiple sequence alignment with Clustal X. Trends Biochemical Sciences, Amsterdam, v. 23, n. 10, p. 403-405, 1998. https://doi.org/10.1016/s0968-0004(98)01285-7

JIN, J. H.; KIM, J. S.; KANG, S. S.; SON, K. H.; CHANG, H. W.; KIM, H. P. Anti-inflammatory and antiarthritic activity of total flavonoids of the roots of Sophora flavescens. Journal of Ethnopharmacology, Ireland, v. 127, n. 3, p. 589-595, 2010. https://doi.org/10.1016/j.jep.2009.12.020

KIM, K. Y.; PARK, S. W.; CHUNG, Y. S.; CHUNG, C. H.; KIM, J. I.; LEE, J. H. Molecular cloning of lowtemperature-inducible ribosomal proteins from soybean. Journal of Experimental Botany, Oxford, v. 55, n. 399, p. 1153-1155, 2004. https://doi.org/10.1093/jxb/erh125

LIAN, Z.; LIU, J.; LI, L.; LI, X.; TUFAN, N. L.; WU, M. C.; WANG, H. Y.; ARBUTHNOT, P.; KEW, M.; FEITELSON, M. A. Human S15a Expression is Upregulated by Hepatitis B Virus X Protein. Molecular Carcinogenesis, Hoboken, v. 40, n. 1, p. 34-46, 2004. https://doi.org/10.1002/mc.20012 
LIU, X. J.; CAO, M. A.; LI, W. H.; SHEN, C. S.; YAN, S. Q.; YUAN, C. S. Alkaloids from Sophora flavescens Aition. Fitoterapia, Amsterdam, v. 81, n. 6, p. 524-527, 2010.

https://doi.org/10.1016/j.fitote.2010.01.008

LOMAKIN, I. B.; STEITZ, T. A. The initiation of mammalian protein synthesis and mRNA scanning mechanism. Nature, Basingstoke, v. 500, p. 307-311, 2013. https://doi.org/10.1038/nature12355

MA, X. C.; XIN, X. L.; ZHANG, B. J.; LI, F. Y.; LIU, K. X.; GUO, D. A. Structural determination of flavonoids from Sorphora flavescens. Magnetic Resonance in Chemistry, Hoboken, v. 46, n. 9, p. 903-906, 2008. https://doi.org/10.1002/mrc.2281

MAGER, W. H. Control of ribosomal protein gene expression. Biochimica et Biophysica Acta, Amsterdam, v. 949, n. 1, p. 1-15, 1988. https://doi.org/10.1016/0167-4781(88)90048-6

MALYGIN, A. A.; PARAKHNEVITCH, N. M.; IVANOV, A. V.; EPERON, I. C.; KARPOVA, G. G. Human ribosomal protein $\mathrm{S} 13$ regulates expression of its own gene at the splicing step by a feedback mechanism.

Nucleic Acids Resarch, Oxford, v. 35, n. 19, p. 6414-6423, 2007. https://doi.org/10.1093/nar/gkm701

MOLLIER, P.; HOFFMANN, B.; DEBAST, C.; SMALL, I. The gene encoding Arabidopsis thaliana mitochondrial ribosomal protein $\mathrm{S} 13$ is a recent duplication of the gene encoding plastid S13. Current Genetics, New York, v. 40, n. 6, p. 405-409, 2002. https://doi.org/10.1007/s00294-002-0271-5

MUHS, M.; HILAL, T.; MIELKE, T.; SKABKIN, M. A.; SANBONMATSU, K. Y.; PESTOVA, T. V.; SPAHN, C. M. Cryo-EM of ribosomal $80 \mathrm{~S}$ complexes with termination factors reveals the translocated cricket paralysis virus IRES. Molecular Cell, Cambridge, v. 57, n. 3, p. 422-432, 2015.

https://doi.org/10.1016/j.molcel.2014.12.016

NAGARAJ, S.; SENTHILKUMAR, M.; RAMU, V. S.; WANG, K.; MYSORE, K. S. Plant Ribosomal Proteins, RPL12 and RPL19, Play a Role in Nonhost Disease Resistance against Bacterial Pathogens. Front in Plant Science, Germany, v. 6, p. 1192, 2016. https://doi.org/10.3389/fpls.2015.01192

NISSEN, P.; STEITZ, T. A. The Structural Basis of Ribosome Activity in Peptide Bond Synthesis. Science, New York, v. 289, n. 5481, p. 920-930, 2000. https://doi.org/10.1126/science.289.5481.920

OZONO, S.; MITSUO, M.; NOGUCHI, M.; NAKAGAWA, S.; UEDA, K.; INADA, H.; OHGA, S.; ITO, E. Critical Diamond-Blackfan anemia due to ribosomal protein S19 missense mutation. Pediatrics International, Hoboken, v. 58, n. 9, p. 930-933, 2016. https://doi.org/10.1111/ped.13018

PORTA, A. R.; MARGOLIS, F. L. Cloning of a cDNA encoding the $\$ 13$ ribosomal protein from the catfish ictalurus punctatus. Gene, Amsterdam, v. 163, n. 2, p. 319-320, 1995. https://doi.org/10.1016/03781119(95)00411-x

QIAN, G.; YANG, Z.; WANG, X.; BUTT, H. I.; CHEN, E.; HE, S.; ZHANG, C.; ZHANG, X.; LI, F. Salicylic acid-related cotton (Gossypium arboreum) ribosomal protein GaRPL18 contributes to resistance to Verticillium dahliae. BMC Plant Biology, Germany, v. 17, n. 1, p. 59, 2017. https://doi.org/10.1186/s12870-017-1007-5

SONG, Y.; HOU, Y. L.; HOU, W. R..; WU, G. F.; ZHANG, T. cDNA, genomic sequence cloning and overexpression of the ribosomal protein $\mathrm{S} 13$ gene in the giant panda (Ailuropoda melanoleuca). Genetics and Molecular Research, Canada, v. 10, n. 1, p. 121-132, 2011. https://doi.org/10.4238/vol10-1gmr1000

STONELEY, M.; WILLIS, A. E. Aberrant Regulation of Translation Initiation in Tumorigenesis. Current Molecular Medicine, Sharjah, v. 3, n. 7, p. 597-603, 2003. https://doi.org/10.2174/1566524033479474 
SUN, M. Y.; CAO, H. Y.; SUN, L.; DONG, S.; BIAN, Y. Q.; HAN, J.; ZHANG, L. J.; REN, S.; HU, Y. Y.; LIU, C. H.; XU, L. M.; LIU, P. Antitumor activities of kushen: literature review. Evidence-based Complementary and Alternative Medicine, New York, v. 2012, n. 4, p. 1-11, 2012. https://doi.org/10.1155/2012/373219

TAMURA, K.; PETERSON, D.; PETERSON, N.; STECHER, G.; NEI, M.; KUMAR, S. MEGA5: Molecular Evolutionary Genetics Analysis Using Maximum Likelihood, Evolutionary Distance, and Maximum Parsimony Methods. Molecular Biology and Evolution, Oxford, v. 28, p. 2731-2739, 2011. https://doi.org/10.1093/molbev/msr121

VAARALA, M. H.; PORVARI, K. S.; KYLLONEN, A. P.; MUSTONEN, M.; LUKKARINEN, O.; VIHKO, P. T. Several genes encoding ribosomal proteins are over-expressed in prostate-cancer cell lines: confirmation of L7a and L37 over-expression in prostate-cancer tissue samples. International Journal of Cancer, Hoboken, v. 78, n. 1, p. 27-32, 1998. https://doi.org/10.1002/(sici)1097-0215(19980925)78:1<27::aid-ijc6>3.0.co;2-z

WANG, W.; YOU, R. L.; QIN, W. J.; HAI, L. N.; FANG, M. J.; HUANG, G. H.; KANG, R. X.; LI, M. H.; QIAO, Y. F.; LI, J. W.; LI, A. P. Anti-tumor activities of active ingredients in Compound Kushen Injection. Acta Pharmacologica Sinica, Shanghai, v. 36, n. 6, p. 676-679, 2015. https://doi.org/10.1038/aps.2015.24

WILLIAMS, A. J.; WERNER-FRACZEK, J.; CHANG, I. F.; BAILEY-SERRES, J. Regulated phosphorylation of 40S ribosomal protein S6 in root tips of maize. Plant Physiology, Rockville, v. 132, n. 4, p. 2086-2097, 2003. https://doi.org/10.1104/pp.103.022749

WILKINS, M. R.; GASTEIGER, E.; BAIROCH, A.; SANCHEZ, J. C.; WILLIAMS, K. L.; APPEL, R. D.; HOCHSTRASSER, D. F. Protein identification and analysis tools in the ExPASy server. Methods in Molecular Biology, Netherlands, v. 112, n. 112, p. 531-552, 1999. https://doi.org/10.1385/1-59259-584-7:531

WOOL, I. G. The structure and function of eukaryotic ribosomes. Annual Review of Biochemistry, Palo Alto, v. 48, n. 48, p. 719-754, 1979. https://doi.org/10.1146/annurev.bi.48.070179.003443

WOOL, I. G. Extraribosomal functions of ribosomal proteins. Trends in Biochemical Sciences, London, v. 21, n. 5, p. 164-165, 1996. https://doi.org/10.1016/s0968-0004(96)20011-8

YANG, X. Y.; CAI, W. M.; YANG, Q. H.; LU, Z. H.; LI, J. S.; YU, J. Compound Radix Sophorae Flavescentis exerts antitumor effects by inhibiting the proliferation and inducing the apoptosis of esophageal carcinoma TE8 cells. Oncology Letters, Athens, v. 10, n. 4, p. 2209-2213, 2015. https://doi.org/10.3892/ol.2015.3607

YUSUPOV, M. M.; YUSUPOVA, G. Z.; BAUCOM, A.; LIEBERMAN, K.; EARNEST, T. N.; CATE, J. H.; NOLLER, H. F. Crystal structure of the ribosome at 5.5 A $^{\circ}$ resolution. Science, New York, v. 292, n. 5518, p. 883-896, 2001. https://doi.org/10.1126/science.1060089

ZHANG, Y.; WOLF, G. W.; BHAT, K.; JIN, A.; ALLIO, T.; BURKHART, W. A.; XIONG, Y. Ribosomal Protein L11 Negatively Regulates Oncoprotein MDM2 and Mediates a p53-Dependent Ribosomal-Stress Checkpoint Pathway. Molecular and Cell Biology, Philadelphia, v. 23, n. 23, p. 8902-8912, 2003. https://doi.org/10.1128/mcb.23.23.8902-8912.2003

ZHANG, J.; YUAN, H.; YANG, Y.; TARA, F.; LYI, S. M.; THANNHAUSER, T. W.; ZHANG, L.; LI, L. Plastid ribosomal protein S5 is involved in photosynthesis, plant development, and cold stress tolerance in Arabidopsis. Journal of Experimental Botany, Oxford, v. 67, n. 9, p. 2731-2744, 2016. https://doi.org/10.1093/jxb/erw106

ZHENG, K. B.; LI, C. H.; SHAN, X. S.; LIU, H. P.; FAN, W. F.; WANG, Z. S. A study on isolation of chemical constituents from Sophora flavescens Ait. and their anti-glioma effects. African Journal of Traditional Complementary and Alternative Medicines, Nigeria, v. 11, n. 1, p. 156-160, 2013. https://doi.org/10.4314/ajtcam.v11i1.24 
ZHENG, M.; WANG, Y.; LIU, X.; SUN, J.; WANG, Y.; XU, Y.; LV, J.; LONG, W.; ZHU, X.; GUO, X.; JIANG, L.; WANG, C.; WAN, J. The RICE MINUTE-LIKE1 (RML1) gene, encoding a ribosomal large subunit protein L3B, regulates leaf morphology and plant architecture in rice. Journal of Experimental Botany, Oxford, v. 67, n. 11, p. 3457-3469, 2016. https://doi.org/10.1093/jxb/erw167 